\title{
SOLIDARITY IN THE DISTRIBUTIVE TRADES IN RELATION TO THE CONTROL OF PRICE COMPETITION
}

\author{
E. T. GRETHER*
}

The problem of this paper is to attempt the hazardous task of interpreting the attitudes of the members of the retail and wholesale trades in relation to the rising tide of demand for legislative control of price competition. The extraordinary temerity of the writer is demonstrated by the census figures for the retail and wholesale trades. The $x 935$ Census of Business listed I,653,96I retail establishments in the United States. Of this total $\mathrm{r}, 474, \mathrm{r} 49$, or $89 . \mathrm{I}$ per cent were classified as independent stores and 127,482 , or 7.7 per cent, as chain stores. The remaining 3.2 per cent were divided among leased departments, utility operated stores, mail order firms, direct selling types and miscellaneous groups, including consumers' co-operatives. The r935 retail sales volume totalled $\$ 33,16 \mathrm{r}, 276,000$ and was divided among the chief competitive types as follows: independent stores 73.I per cent, chain stores 22.8 per cent, all other types 4.I per cent. ${ }^{1}$ For the same year, the Census of Business listed I76,756 wholesale establishments with net sales of $\$ 42,802,913,000 .^{2}$

A wide margin of error may easily creep into any endeavor to survey and interpret attitudes when numbers are so large and conditions so variable and complex. In order to minimize the possibilities of error the writer for the most part will interpret the attitudes of the members of the trades in the State of California. Within California, attention will be given in detail to the food and drug trades, although other lines will be examined to some extent. This interpretation is based not only upon the experience derived from a number of years' residence in the state but from formal research on problems of retail price control during the past three years. ${ }^{3}$ Readers are warned that there may be significant differences in other states and regions; presumably, however, the California experience has meaning beyond

-A.B., 1922, University of Nebraska; M.A., 1923, Ph.D., I924, University of California. Associate Professor of Economics, University of California. Consultant in the Division of Review in the National Recovery Administration, 1935-1936. Author of Resale Price Maintenance in Great Britain (1935) and other works. Contributor to economic and legal periodicals.

${ }^{2}$ U. S. Buresu of the Census, Census of Americhn Business: 1935, Retail Distribution (Vol. IV, Jan. 1937).

Id., Wholesale Distribution (Vol. IV, Feb. 1937).

'The writer plans to publish a summary of the results of this research within a year. References to studies already published will. appear throughoir this paper. 
the borders of the state because of the large degree of homogeneity within the United States. Further, California has been somewhat of a pioneer in the field of legislative restrictions upon price cutting; hence, the California developments are more mature than in the majority of states.

The analysis in this paper will be limited almost entirely to the two chief types of state legislation which are at present most widely prevalent or are being widely considered and pushed; viz., so-called Fair Trade and Unfair Practices Acts. The term "fair trade law" has become attached to those statutes which legalize resale price control by manufacturers of trade marked products. "Unfair practices" acts are not so homogeneous but for the most part have to do with price discrimination between localities and between individuals, loss leader selling and sales below cost where-competitors are injured or destroyed. The core of the so-called unfair practices acts normally is the prohibition of sales below cost in unfair competition. The "unfair practices" type of state legislation in its origin was to a considerable extent the state expression of the anti-price discrimination prohibitions of the Clayton Act.

It should be noted that the problem of this paper is not essentially the economic soundness or unsoundness of the attempts at the control of competition in price. ${ }^{4}$ The general assumption of this paper is that it is as important for purposes of regulation to know the nature of the group pressures in our markets as it is to have theoretical criteria of economic evaluation. At the end of the examination of conditions and attitudes in the trade there will be a brief evaluation of these group attitudes and demands.

Unfortunately even in the field of trading interests, a reasonably realistic appraisal requires the recognition of the play of other motives than those of the "economic man." The economic self-interest of dealers is incased not only in layers of ignorance and prejudice but time and again gives ground to the innumerable influences of an emotional, sentimental and institutional quality. Particularly important always is the factor of leadership in the trade. In the typical trade in which there is a mass of small dealers, it is necessary to recognize at least three zones of variable homogeneity in interests and conduct within this class. There is in the first place, the core of the trade, composed of the officers of the trade association and the active and influential members of the association; and in the second place, a large group of inactive members and others to some degree reached by the association's program; and, finally, often a still larger inchoate group, entirely unorganized, or at best inactive. Not infrequently these smaller operators are unaware of, or uninterested in, the program of the association which claims to represent them. In addition to these gradations of apparent similarity of interests, there is commonly at least a

'The writer's position with respect to these aspects of the problem will be found elsewhere. See, e.g., the following publications by the writer, Resale Price Maintenance in Great Britain (1935); Restriction of Retail Price Cutting With Emphasis on the Drug Industry, Work Materials No. 57, Division og REview, N. R. A. (1936) 187-284; Experience in California With Fair Trade Legislation Restricting Price Cutting (1936) 24 Casif. L. REv. 640; Resale Price Maintenance and the Consumer (r935) 2 Ass. Marketing J. I44-149; Fair Trade Legislation Restricting Price Cutting (1937) I J. of MarketnNe, 344. 
small cluster, often a large grouping, of important and active dissenters, e.g., chain stores, "cut-rate" establishments and sometimes irregular types. Hence, from the standpoint of the problem of this paper it is impossible to understand the degree of solidarity present merely by reference to the official statements of officers of trade organizations. A recognition of this situation tempers the discussion in the pages that follow.

$A$ priori, three groups of general factors seem of largest importance to the understanding of the degree of solidarity that may be achieved. These factors may be classified as follows:

(I) The relative severity and complexity of competition.

(2) The degree of similarity in type and status among the members of the trades.

(3) The general condition of business.

In relation to these three groups of factors three tentative hypotheses may be derived:

I. The more rigorous and complex competition within and between trades is, the greater will be the demand for relief through legislation unless the complexity of the trade has removed the basis of solidarity.

2. Dealers of the same type or status may normally be expected to react similarly.

3. The reactions under (I) and (2) above should be more or less intense as business fluctuates from depression to "prosperity."

The writer feels strongly that it is the convergence of the influences reflected in these three hypotheses that accounts for the extraordinary vigor of the current demands for legislative interference with price competition. Further, except for this confluence of forces there would, for the most part, be either such diversity of interests or inertia as to produce no major. drive for favoring legislation in most lines. Beyond the influences mentioned above, there is one additional significant factor, viz., the rôle of the N.R.A. The N.R.A. not only gave, the members of the trades experience in group action and a pattern for the control of trade practices, but also left them, after the Schechter case, with the husks of frustrated desires. The important point is that the N.R.A. aroused latent and repressed desires and gave them form and direction. There can be little doubt that the impact of this influence is still decidedly effective in the milieu of factors.

In the post war period, the business of getting goods through the channels of distribution has become increasingly complex. So much so, that the process of distribution has become a veritable labyrinth of confusing and conflicting highways and by-ways. Consequently the ordinary dealer often finds himself in the grasp of competitive forces which leave him completely bewildered. He finds himself competing not merely with dealers of similar type and status but with numerous other types of different organizational form, size, policies, etc. For instance, there may be effective competition within a given market between independent unit, specialty and department stores, department stores operated by a chain, or chains of specialty 
stores owned and operated locally, regionally or nationally, mail order houses with or without local stores, the direct-to-consumer efforts of manufacturers through their own stores and/or canvassers, and perhaps consumers' co-operatives or other miscellaneous types. Further, competition is not merely between various types specializing in the sale of the same product but to a large extent between diverse types that have pushed into each other's areas creating so-called "inter-outlet competition" and jurisdictional friction. Even within the group of similar dealers there is conflict because of different buying and merchandising affiliations. Finally, within and between types there is often a tremendous range of variation in merchandising policies. At the one extremity there is scill the full service, specialty and department store; at the other, often some form of limited service, "cut-rate" dealer. Between these extremes not infrequently one finds very great diversity in policy. Without doubt, much of this complexity in our markets represents a better adaptation to the variable tastes, wants and situations of buyers. In any case, however, it often seems to have raised formidable barriers to trade solidarity or to have completely confounded many members of the trade.

Table I portrays the division of the national market between chain and inde-

TABLE I

Comparison of Retail Sales Ratios by Types of Operation, r935, 1933 and I929

\begin{tabular}{|c|c|c|c|c|c|c|c|c|c|}
\hline \multirow[t]{2}{*}{. } & \multicolumn{3}{|c|}{ Independents } & \multicolumn{3}{|c|}{ Chains } & \multicolumn{3}{|c|}{ Other Types } \\
\hline & 1935 & 1933 & 1929 & 1935 & 1933 & 1929 & 1935 & 1933 & 1929 \\
\hline 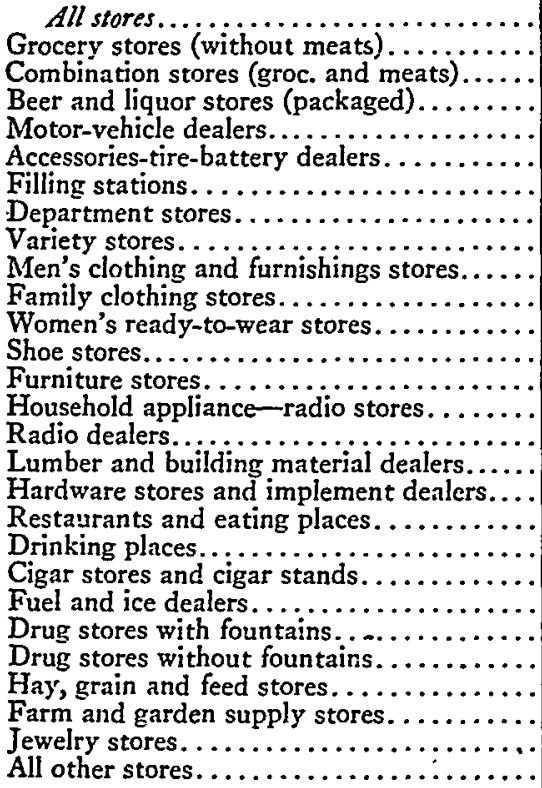 & $\left.\begin{array}{l}73.1 \\
60.8 \\
60.5 \\
48.0 \\
95.6 \\
50.0 \\
77.8 \\
61.4 \\
9.2 \\
78.0 \\
78.9 \\
72.3 \\
43.3 \\
86.0 \\
48.1 \\
75.6 \\
75.6 \\
95.4 \\
84.0 \\
99.2 \\
61.1 \\
82.7 \\
71.1 \\
84.1 \\
71.6 \\
75.0 \\
90.3 \\
78.8\end{array}\right\}$ & $\begin{array}{r}71.3 \\
54.3 \\
56.1 \\
x \\
94.6 \\
x \\
64.3 \\
67.3 \\
8.8 \\
76.5 \\
79.2 \\
74.5 \\
46.5 \\
84.6 \\
33.2 \\
82.7 \\
x \\
95.6 \\
84.8 \\
x \\
65.1 \\
x \\
74.0 \\
x \\
x \\
93.6 \\
79.6\end{array}$ & $\begin{array}{r}77.5 \\
53.6 \\
67.6 \\
x \\
x \\
x \\
66.0 \\
72.1 \\
9.8 \\
77.9 \\
71.5 \\
74.3 \\
53.5 \\
83.9 \\
x \\
79.0 \\
x \\
x \\
86.1 \\
x \\
73.5 \\
x \\
81.2 \\
x \\
x \\
93.0 \\
x\end{array}$ & $\left.\begin{array}{r}22.8 \\
38.2 \\
39.1 \\
1.8 \\
4.4 \\
50.0 \\
21.5 \\
26.7 \\
90.8 \\
21.0 \\
20.6 \\
25.2 \\
50.0 \\
13.5 \\
12.6 \\
23.1 \\
23.8 \\
4.3 \\
14.5 \\
35.1 \\
16.5 \\
28.8 \\
15.4 \\
16.0 \\
4.7 \\
8.9 \\
14.3\end{array}\right\}$ & $\begin{array}{r}25.4 \\
45.0 \\
43.7 \\
x \\
5.3 \\
x \\
35.5 \\
23.9 \\
91.2 \\
22.0 \\
20.3 \\
23.3 \\
46.2 \\
14.2 \\
21.5 \\
15.6 \\
x \\
4.1 \\
14.9 \\
x \\
33.9 \\
x \\
25.1 \\
x \\
x \\
x \\
5.9 \\
15.0\end{array}$ & $\begin{array}{r}20.0 \\
45.7 \\
32.2 \\
x \\
x \\
x \\
33.8 \\
16.7 \\
90.1 \\
21.2 \\
27.3 \\
22.7 \\
38.0 \\
14.2 \\
x \\
19.1 \\
x \\
x \\
13.6 \\
x \\
25.1 \\
x \\
18.5 \\
x \\
x \\
6.4 \\
x\end{array}$ & $\begin{array}{c}4.1 \\
1.0 \\
.4 \\
50.2(\mathrm{a}) \\
\ldots . \\
\ldots . . \\
.7 \\
11.9(\mathrm{~b}) \\
\ldots . . \\
1.0 \\
.5 \\
2.5 \\
6.7(\mathrm{c}) \\
.5 \\
39.3(\mathrm{~d}) \\
1.3 \\
.6 \\
.3 \\
1.5 \\
.7 \\
3.1 \\
.8 \\
.1 \\
.5 \\
12.4(\mathrm{c}) \\
20.3(\mathrm{c}) \\
.8 \\
6.9\end{array}$ & $\begin{array}{r}3.3 \\
.7 \\
.2 \\
x \\
.1 \\
x \\
.2 \\
8.8 \\
.7 .5 \\
1.5 \\
.5 \\
2.2 \\
7.3 \\
1.2 \\
45.3 \\
1.7 \\
x \\
.3 \\
.3 \\
x \\
1.0 \\
x \\
.9 \\
x \\
x \\
.5 \\
5.4\end{array}$ & $\begin{array}{r}2.5 \\
.7 \\
.2 \\
x \\
x \\
x \\
.2 \\
11.2 \\
.1 \\
.9 \\
1.2 \\
3.0 \\
8.5 \\
1.9 \\
x \\
1.9 \\
x \\
x \\
.3 \\
x \\
1.4 \\
x \\
.3\end{array}$ \\
\hline
\end{tabular}

(a) Principally State liquor stores. (b) Principally mail-order (c) Principally leased departments. (d) Principally utility-operated stares. (e) Principally consumer cooperatives. (x) No true comparisons available. 
pendent and miscellaneous types for the years 1929,1933 and $1935 .{ }^{\circ}$ There is also considerable variation between regions and cities. ${ }^{52}$ Finally, (in this connection census figures are of little significance) there is the variation within and between markets in price and service policies. As a consequence of the diversity of types and policies, it would appear that there might be very little basis for agreement among members of the trades with respect to the control of price practices. This conclusion seems particularly appropriate from the standpoint of the division of the total volume of sales for not infrequently it is so proportioned between competing types as to leave no group dominant. However, there are two limiting factors: ( $x$ ) the fact that the smaller dealers normally are clearly dominant in numbers, even if not always in proportion of sales, and (2) there is to some extent sufficient unanimity of interests on certain issues between competitive types to lead to solidarity.

The voting strength (so to speak) of smaller dealers was demonstrated to the writer by a survey of dealer attitudes towards, and experience with, price stabilization made during 1935 in the San Francisco Bay region. At the time of the survey, the N.R.A. experience was still fresh in the minds of these dealers. ${ }^{6}$ Table II summarizes these expressions of opinions of dealers with respect to price stabilization in general, without reference to particular forms of control. The chief opponents almost always were operators of larger stores or of "cut-rate" establishments. Although there were some decided differences between lines, the survey demonstrated clearly that the overwhelming majority of the retail trade favored price stabilization. In fact, agreement was present to some extent even between types, for larger drug chain systems and upper class department stores also preferred some amount of price stabilization.

As part of the general basis for a more detailed discussion, there remains still the problem of the influence of business fluctuations upon dealer attitudes. It would be an over-simplification to assume that the whole movement for price stabilization is a depression phenomenon. As will be noted below, ${ }^{7}$ the cry for resale price control has been heard for many years in the United States. However, the breadth of the movement for price stabilization and its vigor in the last few years can be accounted for only in terms of the rigors of the depression. When prices, and with them volume of sales, slipped downward as the depression lengthened, there was a dual repercussion: first, the general decrease in dollar volume; second, a transfer of

\footnotetext{
¿U. S. Bureat of the Census, Census of American Business: 1935, Retail Distribution (Vol. IV, Jan. 1937).

ca Space does not allow a portrayal of regional and metropolitan variations. Details may be found in the Census report mentioned in note 5 , stupra.

"This survey was made possible by federal relief funds. Although there was a wide coverage of dealers it was not complete because the relief investigators for the most part were directed into the lines for which their experience fitted them. Two notable omissions are grocery stores and drug stores. These lines were covered by the writer in another connection in an intensive investigation of these two fields. In both of these lines, as in most of the other trades, the smaller dealers were in favor of the stabilization of prices by a large majority.

${ }^{7}$ See pp. $381-382$. infra.
} 
TABLE II

Attitudes of Retallers Towards Attempts at Price Stabilization in the San Francisco Bay Region, I935

(Expressed as Percentages of Number Interviewed)

\begin{tabular}{|c|c|c|c|c|}
\hline Lines of Goods Handled & No. of Dealers & In Favor & Opposed & No Opinion \\
\hline 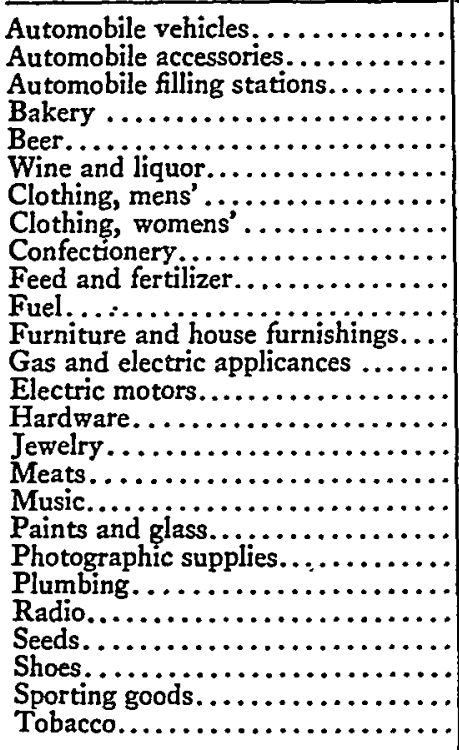 & $\begin{array}{r}77 \\
41 \\
71 \\
116 \\
183 \\
173 \\
34 \\
107 \\
69 \\
18 \\
91 \\
89 \\
109 \\
19 \\
152 \\
54 \\
203 \\
33 \\
171 \\
217 \\
113 \\
123 \\
4 \\
86 \\
112 \\
117\end{array}$ & $\begin{array}{l}87.01 \\
95.12 \\
97.18 \\
94.83 \\
93.98 \\
95.38 \\
70.59 \\
71.96 \\
91.30 \\
77.78 \\
70.33 \\
74.16 \\
95.41 \\
89.47 \\
88.16 \\
79.63 \\
93.10 \\
81.82 \\
97.08 \\
99.08 \\
100.00 \\
90.24 \\
75.00 \\
75.58 \\
97.32 \\
99.15\end{array}$ & $\begin{array}{r}12.99 \\
4.88 \\
2.82 \\
5.17 \\
2.73 \\
4.62 \\
29.41 \\
28.04 \\
2.90 \\
22.22 \\
17.58 \\
25.84 \\
4.59 \\
10.53 \\
6.58 \\
20.37 \\
6.90 \\
18.18 \\
0.58 \\
0.46 \\
7.39 \\
7.32 \\
25.00 \\
23.25 \\
1.79 \\
0.85\end{array}$ & 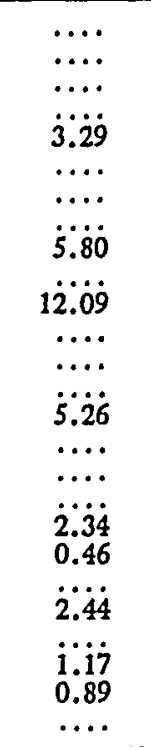 \\
\hline Totals................. & 2582 & 90.70 & 7.78 & 1.52 \\
\hline
\end{tabular}

business to the retail types that sold at lower prices. Dollar volume of retail sales for the United States declined from $\$ 49,114,653,000$ in 1929 to $\$ 25,037,225,000$ in 1933 . Unfortunately there is no measure of the shift to the lower price types of enterprise. Some evidence of the shift is indicated by the fact that the proportion of sales of chain stores from I929 to 1933 increased from 20.0 per cent to 25.4 per cent. It is significant that the chain store ratio by 1935 had fallen to 22.8 per cent. These lower price types were either consistently below the market because of lower costs and limited services, and often because of the sale of distress goods, or gave this impression through the heavy use of loss leaders. The state of affairs in the drug trade in California is without doubt typical for the majority of retail trades. In Table III are listed the summary results of a number of studies of the advertised prices for drug products in California in the spring of 1933 in comparison with the contractual minimum prices in 1934 when these items were controlled by manufacturers' fair trade contracts.

Thus, in the metropolitan centers of California, advertised drug prices in the trough of the depression were approximately 75 per cent of the 1934 contractual prices. The disparity, usually, was less in smaller centers, especially rural towns. 
TABLE III

Comparison of Advertised Prices on Drug Products in California Comamunities During the First Six Months of 1933 with the Stated Praces* aNd with I934 Contractual Prices $†$

\begin{tabular}{|c|c|c|c|c|c|c|}
\hline City or Town & $\begin{array}{c}1930 \\
\text { Population }\end{array}$ & $\begin{array}{l}\text { Number } \\
\text { of } \\
\text { products }\end{array}$ & $\begin{array}{c}\text { Number } \\
\text { of } \\
\text { quotations }\end{array}$ & $\begin{array}{l}\text { Percentage of } \\
\text { Po33 average } \\
\text { actual prices } \\
\text { to average } \\
\text { stated prices }\end{array}$ & $\begin{array}{c}\text { Percentage of } \\
1933 \text { average } \\
\text { actual prices } \\
\text { to } 1934 \\
\text { contractual } \\
\text { prices }\end{array}$ & $\left\{\begin{array}{c}\text { Percentage of } \\
\text { average } \\
\text { stated prices } \\
\text { to the } \\
\text { contractual } \\
\text { prices }\end{array}\right.$ \\
\hline 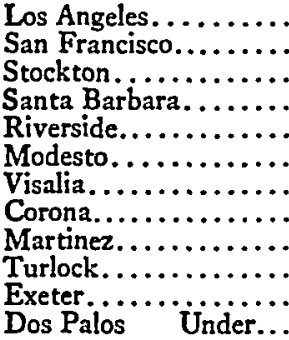 & $\begin{array}{r}1,238,048 \\
634,394 \\
47,963 \\
33,613 \\
29,696 \\
13,842 \\
7,263 \\
7,018 \\
6,569 \\
4,276 \\
2,685 \\
1,000\end{array}$ & $\begin{array}{r}210 \\
134 \\
110 \\
76 \\
53 \\
68 \\
64 \\
20 \\
23 \\
28 \\
22 \\
27\end{array}$ & $\begin{array}{r}966 \\
706 \\
271 \\
183 \\
98 \\
264 \\
270 \\
25 \\
34 \\
41 \\
31 \\
43\end{array}$ & $\begin{array}{l}57.87 \\
57.58 \\
63.70 \\
58.20 \\
61.44 \\
55.37 \\
77.67 \\
68.23 \\
73.37 \\
63.57 \\
84.00 \\
73.57\end{array}$ & $\begin{array}{r}75.31 \\
74.53 \\
78.50 \\
75.40 \\
74.72 \\
69.46 \\
96.41 \\
85.53 \\
84.85 \\
87.44 \\
103.65 \\
87.10\end{array}$ & $\begin{array}{l}131.22 \\
130.41 \\
123.63 \\
130.84 \\
122.05 \\
125.84 \\
122.70 \\
125.17 \\
119.85 \\
131.06 \\
123.85 \\
118.53\end{array}$ \\
\hline
\end{tabular}

The stated price is the price from which the advertiser alleged he was cutting: the actual price is the price at which he was

The contractual price is the minimum or fixed retail price fixed in the manufacturer's resale price maintenance contract with the distributor.

Since these prices were taken from newspapers they represent for the most part the public prices of "cut-rate" firms and chain stores. It is interesting to note that the actual prices were approximately 42 per cent lower than the alleged (stated) prices. This percentage, of course, represents merely a measure of the comparative value claims of the advertisers.

By contrast with the price reductions on the part of the metropolitan "cut-rate" institutions, the great mass of independent druggists held their prices at a much higher level. ${ }^{8}$ Hence, these dealers increasingly were losing business to their lower price, limited service competitors. The same state of affairs existed to some extent in the grocery trade in which the super-market began to flourish; and to a degree, no doubt, in all retail lines. The consequences were twofold: ( $I$ ) the majority of small dealers congealed into a solid block, desirous of price control; (2) some of their arch-competitors, as chain systems and department stores, aligned, themselves with them.

So much for general discussion. In the next place, it is necessary to examine in detail the specific expression of the general demand for some measure of price stabilization. Since the resale price maintenance issue has historical precedence it should be examined first. The large and rapid increase in the sale of products under the brands of manufacturers at the end of the last century and since, created the problem of the degree of control over resale prices which manufacturers could and

\footnotetext{
- For detail, see Grether, Experience in California with Fair Trade Legislation Restricting Price Cutting, supra note 4 , at $677-678$.
} 
should exercise. The problem is not peculiar to the United States but appeared throughout the world, particularly in the highly industrialized countries. In the United States, the issue has been focussed differently from many other parts of the world because resale price maintenance following 1908 was largely unlawful in the United States. ${ }^{\theta}$ Since the problem has been a matter of wide controversy in the United States and elsewhere for at least three or four decades, it cannot be assumed that it was merely a depression phenomenon. For instance, each session of the United States Congress since IgI4 has had one or more bills legalizing resale price maintenance placed before it. The whole issue has been sufficiently acute to produce a number of governmental hearings and a large polemical literature. As a result of the play of interests, controversy and discussion during these years, it is now possible to be fairly specific concerning the nature and intensity of the forces that are effective. Resale price fixing on the part of producers or their representatives can be employed effectively only for a minor portion of the retail business in this country. In the first place, it is applicable only to the differentiated commodities bearing producers' and owners' trade marks. In the second place, either because of lack of interest on the part of manufacturers or because of the serious resistances to effective control, it cannot have general application even within the field of branded goods. ${ }^{10}$ Hence, theoretically the degree of interest in and the amount of support given this form of price stabilization should be related closely to its likelihood of general adoption. Actually, the support nationally and in California has been much broader.

Table IV summarizes the expressed attitudes of retailers in the San Francisco Bay region toward resale price maintenance in 1935 . Particularly important is the large amount of total agreement, as well as the disapproval in certain lines, as in furniture, womens' clothing, and shoes. However, it is extremely important that the interviewers reported that half of the dealers expressing themselves were entirely unfamiliar with the California Fair Trade Law which had been enacted in I93I and amended in 1933. The only conclusion that seems reasonable is that the majority of retailers would express approval of almost any procedure that made for price stabilization even if it had little reference to their own problems. Obviously, the majority could not be actively involved in the organized movement when they were totally unacquainted with the existing statute, in spite of the fact that there had been much discussion of the law throughout the state.

In Tables II and IV the grocery and drug dealers are not included because they were investigated separately. ${ }^{11}$ During the summer of 1934 one hundred retail grocers were interviewed in the San Francisco Bay area. All classes of retail grocers were included in the survey; not merely the members of associations. Fifty-seven per cent of these dealers were at that time unacquainted with the statute. This

- For the general and legal history, see, particularly, Selignsan and Love, Price Cutring and Price Maintenance (1932).

${ }^{10}$ For a discussion of the general resistances to resale price control see Grether, Resale Price MainTENANCE IN Great Britain (1935) 292-300.

It For detail, see the second and third references, supra note 4. 
TABLE IV

Attitudes of Retailers Towards Resale Price Control by Manufacturers in the

SAN Francisco Bay Region, 1935

(Expressed in Percentages of Number Interviewed)

\begin{tabular}{|c|c|c|c|c|}
\hline Lines of Goods Handled & No. of Dealers & In Favor & Opposed & No Opinion \\
\hline 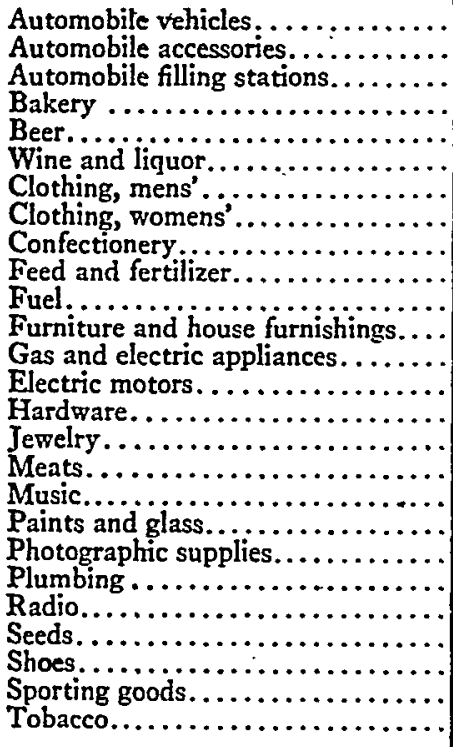 & $\begin{array}{r}77 \\
41 \\
71 \\
116 \\
183 \\
173 \\
34 \\
107 \\
69 \\
18 \\
91 \\
89 \\
109 \\
19 \\
152 \\
54 \\
203 \\
33 \\
171 \\
217 \\
113 \\
123 \\
4 \\
86 \\
112 \\
117\end{array}$ & $\begin{array}{r}92.21 \\
92.68 \\
95.77 \\
89.65 \\
92.90 \\
90.75 \\
85.29 \\
65.42 \\
91.30 \\
83.33 \\
72.53 \\
48.31 \\
96.33 \\
84.22 \\
91.45 \\
68.52 \\
92.12 \\
75.76 \\
95.91 \\
98.16 \\
100.00 \\
89.43 \\
50.00 \\
54.65 \\
91.96 \\
98.29\end{array}$ & $\begin{array}{r}7.79 \\
7.32 \\
4.23 \\
10.35 \\
4.37 \\
9.25 \\
14.71 \\
34.58 \\
4.35 \\
16.67 \\
20.88 \\
47.19 \\
3.67 \\
10.52 \\
5.26 \\
20.37 \\
7.88 \\
24.24 \\
1.75 \\
0.46 \\
7.32 \\
70.00 \\
40.70 \\
8.04 \\
1.71\end{array}$ & 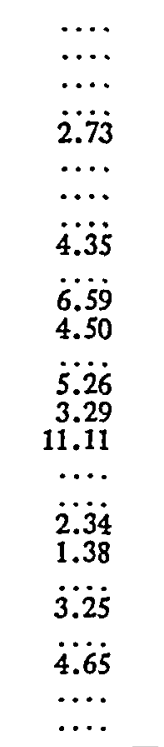 \\
\hline Totals... & 2582 & 87.92 & 10.34 & 1.74 \\
\hline
\end{tabular}

result was particularly surprising because resale price maintenance has been a controversial issue in the grocery trade since the beginning of the century, and the official retail grocers' associations had been active champions of the Fair Trade Law and had taken credit for its passage. The fact that so many retail grocers were unfamiliar with the law is an excellent demonstration of the three zones of influence mentioned above. It should be noted that ninety-one per cent of these dealers, though, expressed approval of resale price fixing. The chief dissenters were the chain stores and smaller firms featuring cut prices.

By way of contrast, the results of a similar survey in 1934 among drug retailers in the San Francisco area is extremely enlightening. In this instance, all were acquainted with the Fair Trade Law. This difference in familiarity is traceable to (I) the fact that the law was being actively employed in the drug trade, (2) the drug trade is smaller, more cohesive and better organized, (3) the higher average level of training and ability in the drug field.

To date, the California Fair Trade Law has been employed most largely in the sale of drug products, and to a considerable extent in the sale of cigars, wines and liquors, photographic supplies, stationery and.office supplies. There has been some 
slight usage in groceries, household furnishings and hardware. Beyond this there has been much discussion with scant results in some other lines. Finally, there are a number of lines where the law would be employed if necessary but where, apparently, equivalent results are obtained without it, as in the book and automotive vehicle lines. As far as the writer knows, this is the situation in other states that have passed fair trade laws. Hence, it is clear that the legislative successes achieved are in spite of the fact that this form of procedure can serve only a minority of the dealers effectively.

The brunt of the legislative battle in California and nationally has been carried by the official organizations of the retail druggists, with some assistance from allied retail associations (such as the grocery, book, hardware, tobacco) and aided by wholesalers' associations and to some extent by manufacturers. Within the last fifteen to twenty-five years there has been a fundamental shift in the alignment of forces. During the early period manufacturers were the prime motivating forces. Today, the retail tradesmen are the most active influential element in the movement. This shift is traceable partly to the increased organizational effectiveness of reailers, but more definitely to the increase in the importance of large scale retail types in the recent period. The increase in the severity of competition congealed the smaller dealers into an effective unit in opposition to department stores, mail order houses, and chain stores who have been the most influential opponents of resale price control. As already noted, during the depression period the effectiveness of smaller "cut-rate" institutions has weaned some of the drug chains too from their early opposition. ${ }^{12}$

The changing status of the trades, as the large scale distributive types became important, has created a serious dilemma for manufacturers when these larger distributors oppose resale price fixing. Further, the more effective organization of the smaller dealers into bargaining groups has complicated the problem for manufacturers. Small dealers, especially in the drug trade, have demonstrated great strength in enforcing boycotts, and particularly in bargaining for what are considered adequate margains. Apparently many manufacturers have become lukewarm about the whole business and would prefer to play a passive rôle. Unfortunately for them, the dealers in their new found strength refuse to allow them to remain aloof. ${ }^{13}$ However, it should be noted that there are many manufacturers, particularly in the drug trade, that are active proponents. ${ }^{14}$

\footnotetext{
${ }^{21}$ It seems clear that the reason for this cliange in attitude was not merely the depression but the general tendency of mature organizations to prefer conservatism and stability to the methods which they employed to purchase their own positions in the market. Further, the extraordinary financial success of the Boots Pure Drug Company in Great Britain amply proves that a large manufacturing and distributing group can thrive under price control. For details, see Grether, Resale Price Manintenance in Great BRITAIN (1935) 307-3Ir.

${ }^{23}$ For examples of manufacturers forced into line by the organized dealers, see Grether, Experience in California with Fair Trade Legislation Restricting Price Cutting, supra note 4, at 672-673.

${ }^{14} \mathrm{Q}$. Forrest Walker, Economist for R. H. Macy \& Company, takes the position that there has been no fundamental realignment of the groups in the trade but that "the manufacturers have remained in the background" and have allowed the public expression to show itself through retail and wholesale associations. See his pamphlet, An Exposé of 'Fair Trade' Lasus (R. H. Macy \& Company, 1937). Quite
} 
Since the last generation, there has also been a fundamental realignment within the wholesale groups. At the beginning of this century when chain stores and co-operative buying groups were in their infancy, and when the channels of trade were much less complex than today, wholesalers often preferred to operate without price restrictions in their markets. In the grocery business in California, for instance, an important group of wholesalers vigorously opposed resale price fixing. ${ }^{15}$ In the recent period, wholesalers can almost always be expected to react with retailers on problems of price control, unless they have moved far from the field of wholesaling per se and have become largely manufacturers or private label houses. In fact, the wholesale druggists and the wholesale grocers are among the most active proponents of resale price maintenance and of sales below cost provisions as well as of the Robinson-Patman Act. With respect to resale price fixing the attitude of the wholesalers is tempered by ( $\mathrm{r}$ ) the fact that they depend upon the large numbers of small dealers for volume, (2) the fact that resale price maintenance tends to reduce the amount of direct selling on the part of manufacturers. If wholesalers succeed in becoming effective policing agents for manufacturers in those fields where resale price fixing is feasible, they should gain greatly under the system; otherwise, the burden of enforcement may lead manufacturers to make more direct contacts.

The forms of procedure other than resale price maintenance are also seen in clearer perspective in California than elsewhere. In IgI3 there was enacted in California a law entitled "The Unfair Competition Act." The core of this act was a provision declaring it unlawful to discriminate between different sections, communities, cities, or between different locations in the state, by selling at a lower rate than justified by quality, quantity, or cost differences "with the intent to destroy competition of any regular established dealer." ${ }^{16}$ A check of retail trade journals in the states indicates that this act aroused no great interest. Apparently its passage reflected merely the general attitude in the United States towards trusts and combinations which produced the Clayton Act in IgI4.

In 1931 the 1913 statute was revived and amended, under the title "The AntiDiscrimination Act." However, the changes were not significant, consisting primarily of slight modifications in the anti-discrimination provisions and in additional penalties. ${ }^{17}$ In 1933 two important amendments were added. In the first, it is stated that the secret payment or allowance of rebates, refunds or commissions, or unearned discounts, whether in the form of money or otherwise, or secretly extending to

possibly some manufacturers who are ardent proponents of resale price fixing might consider it better tactics to have the case presented by and from the retail point of view. However, the writer has in his files reports on interviews with manufacturers which show changes in attitude. Further, as far as California is concerned, the vigour and apparent spontaneity of the movement among retail druggists indicates that it represents a fundamental urge on their part.

${ }^{25}$ For details, see the unpublished M.A. thesis of Lorenzo A. McHenry, of the Graduate School of the University of California, The History of Price Stabilization Attempts in the California Grocery Trade, $1906-1936$.

${ }^{10}$ Cal. Stat. 1913, pp. 508-510.

${ }^{27}$ Cal. Stat. 1931, pp. 1333-1335. 
certain purchasers special services or privileges not extended to all purchasers buying upon like terms and conditions, to the injury of a competitor and where such payment or allowance tends to destroy competition is an unfair trade practice. ${ }^{18}$ In the second amendment, which was entitled "The Sales Below Cost Act," there was the prohibition of sales below cost or the giving away of an article or product "for the purpose of injuring competitors and destroying competition."18

In 1935, this whole group of acts as amended was revised and took the form of the lengthy and now well-known Unfair Practices Act. ${ }^{20}$ The 1935 act reiterated the earlier anti-discrimination provisions as well as the prohibition of secret payments, allowances, etc. Its most significant modification had to do with the 1933 sales below cost provision. Three extremely significant additions were made to it: (I) costs were defined more closely, (2) there was a provision for cost surveys in a trade and in a locality to establish costs, (3) municipal, or other public corporations and trade associations, as well as "persons, firms, and private corporations" were empowered to maintain actions under the act.

Cost of doing business, as applied to production, was defined "as including the cost of raw materials, labor, and all overhead expenses of the producer." As applied to distribution, cost was defined as "invoice or replacement cost, whichever is lower . . . plus the cost of doing business." Cost of doing business, in this instance, was defined as "all costs of doing business incurred in the conduct of such business and must include without limitation the following items of expense: labor (including salaries of executives and officers), rent, interest on borrowed capital, depreciation, selling cost, maintenance of equipment, delivery costs, credit losses, all types of licenses, taxes, insurance and advertising." Exceptions to the sales below cost prohibitions were made (I) in a bona fide closing out sale, and in the sale of seasonal and perishable goods to prevent loss by spoilage and depreciation, (2) in the sale of deteriorated goods when notice thereof is given to the public, (3) in the sale by an officer acting under the orders of a court, and (4) it was held lawful "to meet the legal prices of a competitor" in the same locality or trade area.

In this paper it is largely unnecessary to discuss the problem of the interpretation of these laws, particularly the 1935 act. In brief, it should be noted that (I) diffculties in terminology will likely lead to additional amendments on the part of the 1937 legislature, (2) the basic sales below cost provisions as interpreted and employed have led not to price fixing but merely to establishing low loss limitation floors to markets, (3) the most significant developments have arisen out of trade association activity. Thus the possibilities under the Unfair Practices Act by contrast with the Fair Trade Act are as follows:

${ }^{23}$ Cal. Stat. 1933, p. 793. $\quad{ }^{10}$ Cal. Stat. 1933, pp. 1280-1281.

${ }^{20}$ Cal. Stat. 1935, pp. 1546-155r: All of the prohibitions are limited as in the earlier acts to situations where the intent is "to prevent competition" or is "for the purpose of injuring and destroying compecition." 
I. Action under the Act is horizontal instead of vertical as in the case of resale price maintenance.

2. The protection afforded under the Act, potentially, is universal, and not merely limited to trade marked goods.

3. As employed and interpreted, it does not allow price fixing with full margins but merely restricts price discrimination and curbs loss leader selling.

Unlike the Fair Trade Law, the passage of the significant amendments to the IgI3 Unfair Competition Act in I93I, I933 and I935 seems clearly a depression phenomenon. In fact, proof is written into the 1935 act which was declared "an urgency measure" and ends with the statement that "the sale at less than cost of goods obtained at forced, bankrupt, closeout, and other sales outside the ordinary channels of trade is destroying healthy competition and thereby forestalling recovery. If such practices are not immediately stopped many more businesses will be forced into bankruptcy, thus increasing the prevailing condition of depression." However, in order to appreciate fully the support given the act it is necessary to note two other influences, ( $I$ ) the influence of the N.R.A., and (2) the increased importance of chain stores following the war period and of "cut-rate" establishments during the depression. When the rgr3 act was passed little notice was taken of it in the retail and wholesale trades because chain stores were not as yet major factors in the retail market in California. In the recent period, the small dealers have rallied behind the amended statutes in part, in addition to the depression factors, because they were considered anti-chain.

The associations of independent retailers and of wholesalers have been the influential political forces behind the Unfair Practices type of legislation, even as in the case of the Fair Trade Law. However, in this case the center of the movement was shifted from the drug trade to the grocery trade, aided by allied organizations, particularly in the tobacco trade. The Unfair Practices Act, because of its wider potential coverage, commanded broader support. ${ }^{21}$

One aspect of this support is particularly noteworthy. The provision for trade association activity produced a considerable following among trade association executives who envisaged the possibilities for the expansion of associational activities into the area left open upon the collapse of the N.R.A. In fact, in the grocery trade, the early enforcing agencies were announced as the successors to the Code Authorities.

The ultimate test of solidarity among the members of distributive trades, of course, is not the official public statements of executives of associations, nor the ex-

${ }^{21}$ Specific evidence concerning the variety of support accorded the Unfair Practices Act is given in $T$ he California Retail Grocers' Advocate, March 26, 1937, in a list of associations represented at the conference in Sacramento to recommend revisions of the Act. There were present at the meeting representatives of: The California Retail Grocers' and Merchants' Association, Northern California Retail 'Tobacco Dealers, Northern and Southern California Wholesale Tobacco Dealers, Wholesale Liquor Dealers, Retail Liquor Dealers, Northern and Southern California Retail Druggists' Association, California Printers' Association, California Pharmaceutical Association, Allied Automotive Industries of California, Home Owned Businesses of California, California Lumber Association, California Dyeing and Cleaning Association. 
pressed attitudes pro or con of individual members of trades but the actions of the individual firms under schemes of price stabilization. If "actions speak louder than words" then much of the evidence concerning the general attitude of dealers provided in the preceding pages must be discounted heavily. Apparently for many and often for the majority of dealers, there is a large hiatus between actions and avowed and tacit objectives. It has already been noted that there are often definite differences in attitude between conflicting types within and between trades as well as broad zones of variation within a given grouping of small dealers. These differences between competitive types and within an apparently homogeneous group become even more marked when put to the test of a definite scheme of control.

There is now considerable evidence concerning the quality of actual (as oppposed to lip service) support- given resale price control and the procedure of the Unfair Practices Act in California. In the case of the Fair Trade Act, there can be no doubt that in the retail and wholesale drug trade the gap between expressed aims and actions has been small. Retail druggists have co-operated effectively with their official associations and under the famous so-called "Captain Plan."22 Apparently, much of the same type of vigorous direct action has been effective throughout the country. However, the following exceptional conditions make it unwise to generalize from this experience: (I) the trade has been under extreme pressure, organizationally speaking, and it is dubious that the same degree of fervor will continue indefinitely, (2) as compared with many other lines, druggists represent a small cohesive group with a high level of professional training, (3) much of the gain claimed by, and for, certain manufacturers very likely will be lost to them as the number fixing resale prices increases, (4) when items are relatively inconsequential in the dealer's assembly, the presence or absence of price control may not be the decisive factor determining his attitude, (5) except for periods of extreme pressure, the majority of dealers are apt to follow lines of least resistance and of immediate self-interest in the sale of goods. Even within the drug trade, some manufacturers who in general have supported the movement for resale price control, have become lukewarm or held aloof because they felt that retailers were not co-operating actively with them. Manufacturers have complained on two scores: ( $x$ ) the lack of aggressive, individual selling attention given their controlled lines, (2) the difficulties of enforcement. The latter problem is especially trying for manufacturers. Under the contractual procedure of the fair trade laws, the burden of enforcement rests chiefly with the manufacturers, assisted to some extent by retailers and wholesalers.

To date, in California, there have been many resistances to enforcement, partly because manufacturers have been loath to assume the full burden. Much of this unwillingness, however, reflects some degree of absence of co-operation on the part of the dealers who have fought for the system. Resistances and difficulties such as these are the normal expression of any scheme of price fixing. They could be overcome to a considerable extent in some lines if it is considered lawful in the United

"For details, see the pamphlet by Warnack, The California Fair Trade Act (1935) and Grether, Experience in California with Fair Trade Legislation Restricting Price Cutting, supra note 4. 
States, following the favorable Supreme Court decision in the Illinois and California fair trade cases, to organize associations comprising all the chief factors in the trade as in Great Britain. ${ }^{28}$

In the majority of retail lines it is to be expected that, as far as resale price maintenance is concerned, there would be a decided difference between the opinions and desires of dealers and their conduct. Typically, short run competitive conflicts of interest as well as complexities of merchandising dictate either violations of a fixed price schedule or little or no attempt to push the items so controlled. For instance, in California, since the first decade of this century there have been a number of significant attempts at resale price control in the grocery business. A good portion of the failure of these attempts must be charged not merely to the law and courts, but to the lack of effective co-operation on the part of the members of the trade. Some of this difficulty, admittedly, might be removed by broad and effective cooperation among the members of the trade. However, the resistances are so great that results are bound to be relatively meager compared with: the drug field. Hence, there is no true basis for group solidarity over a period of time. ${ }^{24}$

The procedural difficulties in connection with the use of the Unfair Practices Act well illustrate the same state of affairs. Since the largest development has occurred in the grocery business, the experience in this field is most important. Early in the summer of 1935, following the passage of the Act, the organization of the grocery trade began under its aegis. The Southern California Food and Grocery Bureau was the first organization formed. . Shortly, two major organizations appeared in Northern California; viz., the Food Trades Institute, sponsored by- the California Grocers' and Merchants' Association and the Food Industry Bureau in Alameda and Contra Costa Counties. Similar endeavors appeared throughout the smaller cities in the state, usually in connection with local grocers' associations. The purposes of the various bodies hava been to interpret the Aict to the trade, to obtain compliance amicably when possible, and when necessary to take action in the courts. In the first stage, an attempt was made to levy assessments upon the members of the trade as under the code; however, it was impossible to operate effectively in this manner without power of compulsion. Hence, the expenses have been carried by voluntary contributions, often from a small minority in the trade. The difficulties of financing and supporting the program have led to (I) the placing of an increasing amount of pressure upon the district attorney's office to take action under the Act and (2) the introduction of a bill into the legislature for the establishing of a State Trade Commission to enforce the Act.

Thus, in this instance, as in the case of the Fair Trade Act, the semblance of active, vociferous, public support of price stabilization is often belied by apathy, indifference, and practices derived from immediate, specific competitive expediency.

${ }^{23}$ For a description of British forms of organization and operation, see Grether, Resale Price MainTENANCE IN GREAT BRITAN (1935) 276-292.

"In The California Retail Grocers" Advocate, March 19, I937, there is an anonymous article "Are Fair Trade Acts Desired?" in which retailers are roundly criticised for their lack of merchandising support of the small group of items under contract in-this field. 
Group opinion clearly favors the scheme of price stabilization; individual action often perforates the seemingly solid front. It seems to the writer that a portion of the movement may be expected to wear itself out against enforcement resistances if it continues on a voluntary basis. Even on clear cut issues it is possible to hold the effective support of large groups of small dealers only through exceptional organizational effort. In the recent period, the chain store tax issue was an excellent team mate for the price stabilization proposals. In fact, since the issue in this case was clearly one of independent dealers versus chain stores, the normal assumption would be that the smaller dealers would present a solid front. Yet last fall when the whole matter was placed before the people of the state, the small retailers did not rally behind the tax proposal as a solid unit. It seems likely that the chain store tax measure would have been adopted if there had been effective co-operation among all the retail groups. ${ }^{25}$

In summary it should be noted that:

(I) There is at present apparent pronounced solidarity of interests in the distributive trades with respect to the demand for price stabilization.

(2) The public support for resale price control is broader than its actual possibility of application.

(3) The public expression of this demand for fair trade laws and unfair practices acts in most lines is more pronounced than the actual foundation among the great mass of small dealers.

(4) The vigor of the current movement is to a considerable extent a derivative of the depression and of the N.R.A. experience, and hence may dissipate itself materially if business improvement continues.

(5) Beyond the depression and N.R.A. influences there is the basis for a large permanent demand for the control of price competition because of the increase in the complexity and severity of competition and the improved effectiveness of trade organizations.

In conclusion, a few general comments seem desirable. In the interpretation of group pressures of the sort discussed in this paper, it is essential to keep in mind that short run interests and simple solutions may be expected to be dominant. The great mass of small dealers in the very nature of the circumstances may be expected to confuse immediate and long run forces, and even to disregard completely the ultimate results of their demands. Just as the ordinary person on the street explains the phenomena of depressions in terms of under-consumption and over-production, so the typical small dealer may be expected to assume that his loss of volume is traceable to the nefarious activities of predatory price cutters. The whole issue is confused by the absence of a clear distinction between the sound price reductions that are the essence of the play of supply and demand forces, and price practices in unfair competition. Although the public demand of the official leaders of the movement is for the control of "loss leader" selling; the faith that drives many of their followers is derived from the assumed security that would come from controlled

\footnotetext{
s An example of the dominance of immediate, short run interests as far as many small dealers are concerned is the fact that hundreds of them in the grocery trade are heavy patrons of a leading chain system's wholesale house, in spite of the opposition and efforts of retailers' associations. This state of affairs is an excellent demonstration of the dictatorship of the acute problem of immediate survival.
} 
prices and guaranteed margins. Implicitly, at the core of the movement there is the basis for a program of restrictionism and price fixing, not merely the hope of purging the trades of unfair price practices.

In addition, there is abundant evidence that the proponents of price stabilization are either unaware of or are disregarding the eventual effects of the procedures that they are pushing.' Just as in the case of the Robinson-Patman Act under which the ultimate effects very likely may be decidedly contrary to the expectations, so with the Unfair Practices and Fair Trade Acts. Insofar as the Unfair Practices Acts introduce an apparent element of stability by placing low floors under the markets, they may also, by the same token, increase the rigor of price competition. Price cutting firms, unable to cut a few leaders deeply, must then cut a large number of items thinly. Hence, there is a fundamental readjustment of marking rates and realignment of competitive forces. Evidence to this point is not adequate for thoroughgoing appraisal but it appears that there may even be a slight lowering of the general price level. The smaller dealer would gain only if there were a considerable transfer of patronage from chains and so-called "cut rate" institutions; such a shift would take place only if purchased by these smaller dealers in price competition. A similar situation exists in the case of the Fair Trade Law, although the play of forces is decidedly different. In the relatively small number of fields at present where resale price control can be made effective, there is the strong likelihood that an influx of dealers or an expansion of merchandising services or the growth of private brands would eventually, for the most part, remove the immediate gains, if not destroy them completely. That is, the distributive trades may eventually discover that there are powerful compensatory forces that may remove whatever short run gains are achieved.

However, the movement is sufficiently influential and serious to command the profound attention of economists and political leaders. It is a grave mistake to assume that it will inevitably soon fritter itself to pieces. But it would be a more calamitous error to accept it at its face value and to capitulate to all of its demands. It is high time that the economic issues be stated and that members of the trades and legislators be made aware of the fundamental differences between the control of unfair price practices and generalized schemes of price control. It seems to the writer that in general it is sound public policy to recognize as proper only the elimination of unfair competitive price tactics and to refuse recognition to anything that smacks of price fixing. However, it is essential that some procedure for meeting the demand for the elimination of unfair price practices be provided, if for no other reison than to remove the base of the unsound schemes that range beyond it. Such procedure also would assist vitally in focussing the issues and, hence, it is to be hoped, in clarifying them. There is great danger that the gradual accumulation of unsound legislation will create a situation where the local, state, and federal units of government must eventually become the enforcement agencies for price fixing programs. ${ }^{26}$

\footnotetext{
${ }^{80}$ For instance, at the time of writing, the Board of Supervisors of San Francisco has established a price schedule in the cleaning and dyeing trade.
} 